Paedagogia Christiana

2/28 (201 I) - ISSN 1505-6872

Waldemar Chrostowski*

Warszawa

\title{
Miłość do stworzeń na kartach Biblii
}

Chociaż wszystko, co istnieje, jest Bożym stworzeniem, pojęcie „stworzenia" odnosi się w zasadzie do istot żywych, przede wszystkim do zwierząt, które, tak jak człowiek, żyją i umierają oraz mają zdolność odczuwania. Na kartach Biblii są wzmiankowane zwierzęta, także inne istoty żywe, które w starożytności zamieszkiwały Palestynę i sąsiednie kraje ${ }^{1}$. Natomiast teologiczna refleksja poświęcona zwierzętom nie jest zbyt obfita, co kontrastuje z ich wielością i rozmaitością oraz znaczeniem, jakie im przypada w świecie i w życiu ludzi. Co się tyczy opracowań dotyczących zwierząt, powstałych z powoływaniem się na Biblię ${ }^{2}$, większość autorów poprzestaje na sumarycznej prezentacji odnośnych tekstów biblijnych i podkreślaniu ważnego miejsca zwierząt w Bożym dziele stworzenia oraz potępianiu zachowań ludzi krzywdzących zwierzęta, zwłaszcza okrucieństwa wobec nich. Nie bra-

* Ks. prof. zw. dr hab. Waldemar Chrostowski jest kierownikiem Katedry Egzegezy Starego Testamentu na Wydziale Teologicznym Uniwersytetu Kardynała Stefana Wyszyńskiego w Warszawie.

${ }^{1}$ Zwięzłą prezentację zob. w rozdziale Zwierzęta i owady Palestyny, w: J. I. Packer, M. C. Tenney (red. nauk.), W. Chrostowski (red. nauk. wyd. pol.), Stownik tła Biblii, Warszawa 2007, s. 171-196; a także w: B. Szczepanowicz, A. Mrozek, Atlas zwierzat biblijnych. Miejsce w Biblii i symbolika, Kraków 2007 (rec.: W. Chrostowski, „Collectanea Theologica” 1 [2008], s. 219-222).

${ }^{2}$ W Bibliografii biblistyki polskiej 1945-1999, autorstwa P. Ostańskiego (Poznań 2002), obejmującej ponad 23 tys. pozycji, pod hasłem „zwierzęta” wyszczególniono 24 publikacje; z kolei w Bibliografii biblistyki polskiej 2000-2009, tegoż autora (Poznań 2010), obejmującej około 500 publikacji mniej, pod hasłem „zwierzęta” wyszczególniono 66 publikacji. Dowodzi to wyraźnego wzrostu zainteresowania tą problematyką w ostatnich latach. 
kuje też przemyśleń, w których podkreśla się przeciwstawianie człowieka potędze świata zwierzęcego oraz podkreśla wieloraką przewagę nad zwierzętami. W ostatnim okresie pojawiają się również próby wykorzystywania refleksji teologicznej dotyczącej zwierząt w argumentacji nawołującej do zaniechania spożywania mięsa i prowadzenia wegetariańskiego stylu życia.

Potrzeba jednak czegoś więcej, a mianowicie prawdziwie teologicznego fundamentu dla szacunku, a nawet, nie wahajmy się użyć tego określenia, dla miłości wobec zwierząt, postrzeganych i traktowanych jako stworzenia stanowiące integralny składnik Bożego świata, a co za tym idzie, także pełniejszego dowartościowania ich miejsca i roli w Bożym planie zbawienia urzeczywistnionym w Jezusie Chrystusie ${ }^{3}$. $Z$ tego względu niezbędne jest pogłębione i pełniejsze osadzenie i rozwijanie chrześcijańskiej teologii zwierząt w orędziu obydwu części Pisma Świętego, to jest zarówno w Starym, jak i w Nowym Testamencie ${ }^{4}$.

\section{1. „Pan jest dobry dla wszystkich i Jego milosierdzie ogarnia wszystkie Jego dzieła" (Ps 145, 9)}

Biblijne spojrzenie na zwierzęta oraz odnoszące się do nich praktyczne imperatywy moralne opierają się przede wszystkim na przesłankach wynikających z prawdy o stworzeniu świata i człowieka przez Boga. Napisano i powiedziano na ten temat bardzo wiele, opierając się przede wszystkim na dwóch otwierających Biblię tekstach (Rdz 1, 1-2, 4a oraz 2, 4b-24), które stanowią ważny kod kulturowy naszej cywilizacji ${ }^{5}$. W pierwszym, traktowanym jako opowiadanie o stworzeniu świata bądź hymn ku czci Boga Stwórcy,

${ }^{3} \mathrm{~W}$ ostatnim okresie dobry przykład pogłębienia chrześcijańskiego spojrzenia teologicznego, podjętego i rozwijanego w niniejszym tekście, stanowi publikacja: A. Linzey, Teologia zwierząt, Kraków 2010 (rec.: W. Chrostowski, „Collectanea Theologica” 4 [2010], s. 233-237).

${ }^{4}$ Zob. także W. Chrostowski, Dobroć wobec zwierząt w świetle Biblii, w: tenże (red.), „Pieśniami dla mnie Twoje przykazania”. Ksiegga pamiatkowa dla Księdza Profesora Janusza Frankowskiego w 50. rocznicę święceń kapłańskich i 75. rocznicę urodzin, Warszawa 2003, s. 95-115; tenże, Status zwierząt w świetle Biblii, „Forum Teologiczne” 6 (2005), s. 7-22; obydwa teksty zostały zamieszczone w: tenże, Babilońskie deportacje mieszkańców Jerozolimy $i$ Judy oraz inne studia, Rozprawy i Studia Biblijne 34, Warszawa 2009, odpowiednio s. 321-341 oraz 301-320.

${ }^{5}$ Zob. np. syntezę podaną w: D. G. Deffenbaugh, D. L. Dundan, Biblia i ekologia, w: W. R. Farmer (red.), W. Chrostowski (red. nauk. wyd. pol.), Międzynarodowy komentarz do Pisma Świętego. Komentarz katolicki i ekumeniczny na XXI wiek, Warszawa 2001, s. $1762-1769$. 
które przedstawia prawdę o stworzeniu w schemacie siedmiu dni tygodnia zwieńczonych szabatem, po trzech dniach ,przygotowania sceny” (Rdz 1, 3-13) następują trzy dni jej ,zapełniania” (1, 14-25), w których stworze-

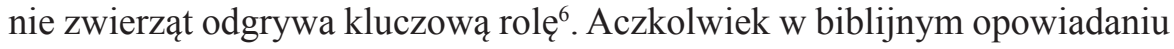
istnieją zapewne ślady polemiki z przyjętym w wielu religiach pogańskich ubóstwianiem zwierząt i uprawianiem kultu ich podobizn ${ }^{7}$, prawdą jest jednak, że zwierzęta, stworzone przez Boga zanim pojawiła się pierwsza para ludzka, zyskały status naszych ,starszych braci”». Wszystkie stworzenia stanowią harmonijną całość, swoistą wspólnotę, której źródłem i przeznaczeniem jest Ten, który je powołał do istnienia. Wszystkie są wartościowe, bo jako takie zamierzył je Bóg i to On sprawił istnienie wszystkich.

Zaistnienie człowieka, stworzonego z materii, lecz odmiennego od reszty stworzeń, ponieważ stanowi „obraz i podobieństwo” Boga ( $R d z 1,26)$, jest związane z błogosławieństwem płodności i przykazaniem: „Bądźcie płodni i rozmnażajcie się, abyście zaludnili ziemię i uczynili ją sobie poddaną; abyście panowali nad rybami morskimi, nad ptactwem powietrznym i nad wszystkimi zwierzętami pełzającymi po ziemi” $(1,28)$. „Panowanie” człowieka nad światem nie oznacza wyzysku ani przemocy, lecz ogromną odpowiedzialność za dzieło stworzenia powierzone mu przez Boga ${ }^{9}$. Na osobną uwagę zasługuje błogosławieństwo płodności, najpierw dotyczące zwierząt („Bądźcie płodne i mnóżcie się, abyście zapełniały wody w morzach, a ptactwo niechaj się rozmnaża na ziemi" - w. 22), a następnie skierowane do ludzi („Bądźcie płodni i rozmnażajcie się”). Nie ulega żadnej wątpliwości, że prokreacja - w obu przypadkach wpisana w dynamizm Bożego dzieła stworzenia i stale ponawiana - stanowi przedłużenie absolutnie unikatowego aktu kreacji. Różnica polega na tym, że tylko ludzie są świadomi tych więzi. Jak refren powtarzają się słowa, że wszystko, co Bóg uczynił, było „dobre” $(1,3.10 .12 .18 .21 .25)$, zaś całość stworzenia - „,bardzo dobra” (w. 31).

${ }^{6}$ Por. H. Witczyk, Stworzenie a ekologia w świetle Rdz 1, 1-2, 3, „Człowiek i Przyroda” 10 (1999), s. 41-56.

7 P. Lamarche, Zwierzęta, w: X. Leon-Dufour (red.), Stownik teologii biblijnej, Poznań-Warszawa 1973, s. 1148-1149.

8 Jeden z moich wywiadów prasowych, poświęcony potrzebie dobroci wobec zwierząt, został opatrzony tytułem Nasi bracia starsi („Gazeta Pomorska” nr 70 z dn. 23-24.03.2002, s. 7 - rozmawia Teresa Słocińska). W bibliografiach sporządzonych przez autorów, którzy nie zadali sobie trudu zapoznania się z jego treścią, włączono go do publikacji poświęconych problematyce dialogu Kościoła z Żydami i judaizmem.

9 J. Suchy, Czyńcie sobie ziemię poddana, panujcie nad zwierzętami, „Zeszyty Naukowe Katolickiego Uniwersytetu Lubelskiego" 1-4 (1993), s. 13-23. 
Drugie opowiadanie o stworzeniu świata i człowieka (Rdz 2, 4b-24), niepozbawione elementów wysublimowanego humoru, przedstawia zwierzęta w relacji do ludzi, potwierdzając, że nie są w stanie sprostać poczuciu samotności wynikającemu z braku czy nieobecności drugiego człowieka. Po Bożej diagnozie: „Nie jest dobrze, żeby mężczyzna był sam” $(2,18)$ następuje wspaniały epizod lepienia i ożywiania rozmaitych istot (obraz Boga jako garncarza), które Bóg przyprowadza do mężczyzny, ,aby przekonać się, jak on je nazwie" $(2,19)$. W konfrontacji ze zwierzętami człowiek uświadamia sobie to, co go od nich różni, a co jednocześnie buduje i wzmacnia poczucie jego tożsamości. W tych okolicznościach dochodzi do przekonania, że samotność jest jego wrogiem i że zwierzęta nie są w stanie przezwyciężyć jej poczucia, wynikającego z potrzeby innego człowieka ${ }^{10}$. $\mathrm{W}$ obu otwierających Biblię opowiadaniach doniosłe znaczenie ma ukazany w nich aspekt harmonii stworzonego świata. Konkluzja jest oczywista: każdy gwałt i przemoc wobec zwierząt stanowią przejaw zepsucia traktowanego jako grzech i sprzeciwiają się zamysłowi, który znalazł wyraz w Bożym dziele stworzenia.

Odpowiedzialność za dzieło stworzenia, którego szczególną częścią są wszystkie istoty żywe, dostarcza bezpośredniej motywacji do tworzenia zasad moralnych i reguł prawnych określających postawę i nastawienie względem ,starszych braci”. Ich tło stanowi przeświadczenie, że istnieje silny kontrast między ideałem wyrażonym w pięknych opowiadaniach o stworzeniu świata i człowieka a rzeczywistością, w jakiej żyjemy, naznaczoną niezliczonymi przejawami zła i zepsucia, których ofiarami stają się również zwierzęta. Przyczynę tego rozdźwięku stanowi grzech, którego dopuścił się człowiek, na skutek czego świat został dotknięty i skażony przez zło. Jednym ze skutków zachwiania pierwotnej harmonii zamierzonej i urzeczywistnionej przez Boga stało się spożywanie mięsa. Pierwotny zamysł Boży był inny. W opowiadaniu o stworzeniu pierwszej pary ludzkiej czytamy: „I rzekł Bóg: «Oto wam daję wszelką roślinę przynoszącą ziarno po całej ziemi i wszelkie drzewo, którego owoc ma w sobie nasienie; dla was będą one pokarmem. A dla wszelkiego zwierzęcia polnego i dla wszelkiego ptactwa powietrznego i dla wszystkiego, co się porusza po ziemi i ma w sobie pierwiastek życia, pokarmem będzie wszelka trawa zielona»" (1,29-30). Grzech, jako skutek zła, wprowadził w świat nieporządek wynikający z wtargnięcia i nasilania się wzajemnej wrogości (Rdz 3, 14-19), kładąc kres pierwotnej harmonii. Gdy pierwsi rodzice odkryli swą nagość, zostali ubrani w „odzienie ze skór”

${ }^{10}$ Szerzej: W. Chrostowski, Samotność w Biblii, w: A. Matusiak (red.), Samotność chciana i niechciana, Kraków 2002, s. 31-52. 
zwierzęcych $(3,21)$. Wprawdzie ludzkość pochodząca od Kaina, zabójcy Abla, swego brata, wyginęła w potopie, ponieważ przetrwał tylko sprawiedliwy Noe oraz jego najbliższa rodzina, wywodzący się od Seta ( Rdz 6, 5-8, 19), ale świat, jaki wyłonił się z potopu, nie był już tak harmonijny jak na początku. Zwierzęta współuczestniczyły w dramacie ludzi: ogromna większość zginęła w odmętach potopu, zaś te, którym ocalono życie, stanowiły składnik odnowionego świata. W świecie przed potopem istniało zabijanie zwierząt, składano je bowiem na ofiarę Bogu ( $\operatorname{Rdz} 4,4)$, ale błogosławieństwo płodności przeznaczone dla Noego i jego synów zyskało nowe akcenty, dramatyczne i w pewien sposób mroczne, gdyż naznaczone piętnem skażenia grzechem: „Bądźcie płodni i mnóżcie się, abyście zaludnili ziemię. Wszelkie zaś zwierzę na ziemi i wszelkie ptactwo podniebne niechaj się was boi i lęka. Wszystko, co się porusza na ziemi i wszystkie ryby morskie zostały oddane wam we władanie. Wszystko, co się porusza i żyje, jest przeznaczone dla was na pokarm, tak jak rośliny zielone - daję wam wszystko" (Rdz 9, 2-3). Pierwotną harmonię zastąpił lęk zwierząt przed człowiekiem, wpisany niejako odtąd w ich naturę, w wyniku czego są płochliwe i nie pozwalają ludziom zbliżać się do siebie. Drugi aspekt to dopuszczenie spożywania ich mięsa, a więc konieczność pozbawiania ich życia. Można bez żadnej przesady powiedzieć, że zwierzęta, a także wszystkie inne istoty żywe, wodne i powietrzne, zapłaciły najwyższą cenę za nieposłuszeństwo wobec Boga oraz zło, jakiego dopuścili się ludzie.

Mając na uwadze świat, w którym istnieje zabijanie i pozbawianie życia, wiele rozporządzeń Pięcioksięgu dotyczy tej problematyki, zakazując złego traktowania zwierząt i stosowania wobec nich okrucieństwa. Prawodawstwo Pięcioksięgu stanowi podstawę prawodawstwa judaistycznego, zawartego w nauczaniu rabinów utrwalonym w Talmudzie i innych źródłach judaizmu rabinicznego ${ }^{11}$. Zabijanie zwierząt celem pozyskania ich mięsa zostało obwarowane rozmaitymi przepisami, które stanowią integralną część tak zwanego prawa koszerności. Zabijanie zwierząt, aczkolwiek dopuszczalne, bo konieczne do przetrwania, jest postrzegane jako specyficzna niestosowność: „Gdy Pan, Bóg twój, rozszerzy twoje granice, jak ci przyrzekł, a ty powiesz sobie: «Chcę spożywać mięso, ponieważ zapragniesz spożywać mięso, możesz spożywać mięso do woli»” (Pwt 12, 20). W wykładni rabinów czasownik hebrajski przełożony na język polski jako ,zapragniesz” ma wydźwięk negatywny i tak właśnie powinien być rozumiany i objaśniany. Aczkolwiek Biblia dopuszcza zabijanie zwierząt, by pozyskać ich mięso, zna

11 Zob. hasło Animals, Attitudes to, w: G. Wigoder (red.), The Encyclopedia of Judaism, Jerusalem 1989, s. 60-61; por. Sh. Bakon, Not to Inflict Hurt on Animals, "Jewish Bible Quarterly" 3 (1996), s. 149-155. 
też rozmaite sposoby polowania na dziką zwierzynę $e^{12}$, judaizm, co znalazło wyraz w Talmudzie (Avodah zara 18b), zabrania polowań traktowanych jako zabijanie zwierząt dla przyjemności. Wielu komentatorów żydowskich podkreśla fakt, że jedyni myśliwi, o jakich mowa na kartach Biblii, to Nimrod (Rdz 10, 9) i Ezaw (Rdz 27, 3-4), zaś Izraelici nie powinni ich naśladować ${ }^{13}$. Religijnie motywowana powściągliwość przed odbieraniem życia zwierzętom stoi u podstaw szczegółowych rozporządzeń regulujących przebieg ich uboju dla potrzeb spożywczych. Wspólnym mianownikiem tych regulacji jest nacisk na obowiązek oszczędzenia, na tyle, na ile to możliwe, zwierzętom lęku i bólu.

Skoro obraz stworzenia świata i człowieka został zbudowany z wykorzystaniem nieustannie powtarzanego rytmu tygodnia, którego zwieńczeniem jest szabat, nic dziwnego, że i zwierzęta mają swój udział w obchodach tego dnia, który jest uważany za święty. Chodzi przy tym o ich los uwarunkowany świadomością wyznawców jedynego Boga, zachowujących pamięć o wybawieniu z Egiptu dokonanym przez Boga: „Dzień zaś siódmy jest szabatem Pana, Boga twego. Nie będziesz zatem w tym dniu wykonywał żadnej pracy ani ty sam, ani twój syn, ani twoja córka, ani twój niewolnik, ani twoja niewolnica, ani twoje bydło, ani przybysz, który przebywa w twoich bramach" (Wj 20, 10; por. Pwt 5, 14). Tak samo jak ludzie, również zwierzęta potrzebują odpoczynku, który im się słusznie należy: „Sześć dni będziesz pracował, a dnia siódmego zaprzestaniesz pracy, aby odpoczął twój wół i osioł i odetchnęli syn twojej niewolnicy i cudzoziemiec" (Wj 23, 12). Warto zauważyć, że w przytoczonych tekstach biblijnych wzmianka o zwierzętach poprzedza „przybysza, który przebywa w twoich bramach” oraz ,syna twojej niewolnicy i cudzoziemca". Rabini upatrywali w tym wskazówkę, że zanim wszyscy domownicy rozpoczną szabatowy odpoczynek, konieczna jest $\mathrm{z}$ ich strony troska o zwierzęta, które potrzebują życzliwości i pomocy swoich właścicieli i nadzorców. Wymowna jest rabiniczna interpretacja zapowiedzi obfitości dóbr zapewnionych przez Boga po wejściu do Ziemi Obiecanej: „Da [Bóg] też trawę na polach dla waszego bydła i będziecie mieli żywności do syta" (Pwt 11, 15). Podkreślając fakt, że bydło zostało wymienione przed ludźmi, rabini upatrują w tym tekście biblijne uzasadnienie polecenia nakarmienia zwierząt, zanim do posiłku zasiądą ich właściciele: „Zakazany jest człowiekowi posiłek zanim nie nakarmi swojego zwierzęcia, bo zwierzę

${ }_{12}$ Zob. np. Polowanie, w: F. Rienecker, G. Maier, W. Chrostowski (red. nauk. wyd. pol.), Leksykon biblijny, Prymasowska Seria Biblijna 18, Warszawa 2001, s. 909.

${ }^{13}$ W tym miejscu nie sposób nie postawić pytania, czy wiedzą o tym myśliwi-chrześcijanie, a także ich kapelani, zwłaszcza podczas uroczystych obchodów św. Huberta, patrona myśliwych, zapoczątkowujących coroczny sezon myśliwski. 
zostało wzmiankowane jako pierwsze" (Ber. 40a) ${ }^{14}$. Ta zasada została prawnie skodyfikowana przez Majmonidesa (Yad, Avadim 9,8) i należy do halachicznego kanonu judaizmu. Podobny sens mają kilkakrotnie powtórzone rozporządzenia z Talmudu Jerozolimskiego zakazujące nabywania zwierząt, jeżeli ich przyszły właściciel nie byłby w stanie zapewnić im godziwego utrzymania (Yev., 15,3; Ket 4,8.29a).

W tym samym kontekście należy umieścić rozporządzenia nakazujące wrażliwość wobec zwierząt, pojmowaną jako skuteczna troska o ich dobro$\operatorname{stan}^{15}$. Wyraźny respekt dla nich rozpoznajemy w przepisach dotyczących obchodów roku szabatowego: „Szabat ziemi będzie służył wam za pokarm: tobie, słudze twemu, służącej twej, najemnikowi twemu i osiadłym u ciebie przybyszom. Cały jego plon będzie służyć za pokarm także twojemu bydłu i zwierzętom, które są w twoim kraju” (Kpł 25, 6-7). Wzgląd na wyjątkowy status macierzyństwa tłumaczy przepis, który brzmi: „Nie będziecie tego samego dnia zabijać krowy albo owcy razem z jej małym” (Kpł 22, 28). W podobnym duchu należy odczytywać przepis dotyczący ptactwa: „Jeśli napotkasz przed sobą na drodze, na drzewie lub na ziemi, gniazdo ptaka z pisklętami lub jajami wysiadywanymi przez matkę, nie zabierzesz matki z pisklętami. Matkę wypuścisz wolno, a pisklęta możesz zabrać; aby ci się dobrze powodziło i abyś długo żył" (Pwt 22, 6-7). Wypuszczenie ptasiej matki ma na celu oszczędzenie jej cierpienia na widok zabieranych piskląt. To rozporządzenie dotyczące ptactwa rozciągano na wszystkie istoty żywe, nakładając na wyznawców Boga obowiązek wrażliwości wobec nich. Rabini dopowiadali, że postulat współczucia wobec zwierzęcych i ptasich rodziców pozostaje w związku z przykazaniem czci własnych rodziców. Ponadto, zwracając uwagę na osobliwe połączenie polecenia wypuszczenia ptasiej matki z obietnicą powodzenia i długiego życia, obecne również w przykazaniu czci rodziców, komentowali ten werset jako potwierdzenie, że człowiek zostanie potraktowany na sądzie przez Boga stosownie do tego, jak traktuje zwierzęta. Wyznawcy Boga nie może być obojętny dobrostan zwierzęcia wykonującego ciężką pracę: „Nie zawiążesz pyska wołowi młócącemu” (Pwt 25, 4). Obowiązek wrażliwości i pomocy dotyczy zwierząt, które same sobie nie poradzą - i to nawet wtedy, gdy stanowią własność osób postrzeganych jako wrogowie: ,Jeśli spotkasz wołu twego wroga albo jego osła błąkającego się, odprowadź je do niego. Jeśli zobaczysz, że osioł twego wroga upadł pod swoim ciężarem, nie pozostawisz go, ale razem z nim przyjdziesz

${ }^{14}$ Sh. Bakon, dz. cyt., s. 151.

15 J. A. Grassi, Animal Rights and Justice in the Biblical Tradition, "The Bible Today" 6 (2001), s. 373-378. 
mu z pomocą" (Wj 23, 4-5). Nie wolno przenosić na zwierzęta bolesnych konsekwencji wrogości, która dzieli ich właścicieli.

Analogiczne zapatrywania, życzliwe wobec zwierząt i podkreślające więzi ich solidarności z ludźmi, odnajdujemy w narracyjnych fragmentach Starego Testamentu. Rebeka, matriarchini Izraela, jest chwalona za systematyczna troskę o trzodę ojca i dobry uczynek napojenia wielbłądów (Rdz 29, $1-9)$. Balaam został surowo napomniany za bicie swojej oślicy (Lb 22, 32), której przezorność ocaliła życie pogańskiego proroka. Eliasz zawdzięczał swoje przetrwanie krukom, które go karmiły podczas samotnego pobytu na pustyni $(1 \mathrm{Krl} \mathrm{17,6).} \mathrm{„Wielka} \mathrm{ryba”} \mathrm{ocaliła} \mathrm{Jonasza} \mathrm{od} \mathrm{śmierci} \mathrm{na} \mathrm{morzu,}$ zapewniając mu przetrwanie sprzyjające nawróceniu, które znalazło wyraz w posłuszeństwie Bogu (Jon 1-2). Zwierzęta podzielają postawę pokutujących Niniwitów (Jon 3, 8). To, że los zwierząt nie jest Bogu obojętny, zyskuje wymowne potwierdzenie w pytaniu retorycznym, którym kończy się Księga Jonasza: „A czyż Ja nie powinienem okazać litości Niniwie, wielkiemu miastu, gdzie znajduje się więcej niż sto dwadzieścia tysięcy ludzi, którzy nie odróżniają swej prawej ręki od lewej, a nadto mnóstwo zwierząt?" (Jon 4, 11). W tym samym nurcie należy umieścić wskazania zawarte w hagadycznym tworzywie starożytnej oraz późniejszej tradycji żydowskiej. Talmud Jerozolimski objaśnia, że Mojżesz i Dawid otrzymali przywilej przewodzenia i królowania, dlatego że obaj byli pasterzami wyczulonymi na los swoich zwierząt (Kil. 9,3; 32a; Baba Mec. 85a). Rabin Jehuda ha-Nasi, bardzo zasłużony jako kodyfikator Miszny (ok. 220 r. po Chr.), widząc wystraszonego cielca prowadzonego na rzeź, który szukał u niego schronienia, zaprowadził go do rzeźników, za co spotkała go kara Boża w postaci długotrwałej choroby, która została odwołana dopiero wtedy, gdy zrozumiał swój błąd i zmienił postępowanie.

Wzgląd na rozmaite zwierzęta, których życie i przetrwanie stanowi wielką zagadkę i jest godne najwyższego podziwu, prowadzi Hioba do uznania potęgi Stwórcy (Hi 38, 39-39, 30; 40, 15-41, 26), a w konsekwencji również do pokory wobec pytania o sens cierpienia niewinnych i znaczenie obecności cierpienia w świecie. Także w psalmach wielokrotnie pojawia się motyw opatrznościowej troski Boga o wszystkie istoty żywe: „Wszystko to czeka na Ciebie, byś dał im pokarm w swoim czasie” (Ps 104 [103], 27). Oraz: „Oczy wszystkich wyglądają Ciebie, Ty zaś dajesz im pokarm we właściwym czasie. Ty otwierasz swą rękę i wszystko, co żyje, nasycasz do woli” (Ps 145 [144], 15-16). Nieco dalej psalmista wielbi Boga za Jego opatrznościową obecność w świecie, gdyż „On daje pokarm bydłu, a pisklętom kruka to, o co wołają" (Ps 147 [146-147], 9). Mnóstwo nawiązań do zwierząt i roślin znaj- 
dujemy w Pieśni nad pieśniami, która stanowi jedną z najwymowniejszych ilustracji głębokiego przywiązania i miłości do Ziemi Świętej ${ }^{16}$.

Zło i grzechy, których dopuszczają się ludzie, nie pozostają bez wpływu na kondycję innych stworzeń. Prorok Ozeasz wołał:

Słuchajcie słowa Pana, synowie Izraela,

On bowiem spór wiedzie z mieszkańcami kraju,

gdyż zaginęły wierność i miłość

oraz znajomość Boga na ziemi.

Przeklinają, kłamią, mordują i kradną,

cudzołożą, popełniają gwałty, a zbrodnia idzie za zbrodnią.

Dlatego kraj jest okryty żałobą

i więdną wszyscy jego mieszkańcy,

zarówno zwierz polny, jak ptactwo powietrzne,

a nawet ryby morskie marnieją $(\mathrm{Oz} 4,1-3)$.

Zniszczenie spowodowane przez grzech i zło dotyka nie tylko ludzi, lecz całej wspólnoty istot żywych. Ponieważ zwierzęta mają współudział w losach człowieka i świata, zatem obejmuje je również - przeczuwane i zapowiadane na kartach Biblii - zbawcze działanie Boga. Ta intuicja i tęsknota była wyraźnie obecna już na kartach Starego Testamentu. Zapowiadając cud nowego Wyjścia, Bóg ustami proroka (Deutero)Izajasza wołał: „Sławić Mnie będą zwierzęta polne, szakale i strusie, / gdyż na pustyni dostarczę wody i rzek na pustkowiu, / aby napoić mój lud wybrany" (Iz 43, 20).

Obietnica powszechnego królestwa pokoju, z poetyckim rozmachem ukazana przez (Proto)Izajasza, obejmuje również zwierzęta:

Wtedy wilk zamieszka wraz z barankiem,

pantera $\mathrm{z}$ koźlęciem razem leżeć będą,

cielę i lew paść się będą pospołu

i mały chłopiec będzie je poganiał.

Krowa i niedźwiedzica przestawać będą ze sobą przyjaźnie,

młode ich razem będą legały.

Lew też jak wół będzie jadał słomę.

Niemowlę igrać będzie na gnieździe kobry,

dziecko włoży swą rękę do kryjówki żmii.

Zła czynić nie będą ani działać na zgubę

${ }^{16}$ Zob. np. liczne wzmianki w: G. Ravasi, Pieśń nad pieśniami... jak pieczęć na twoim sercu, Kraków 2005. 
po całej świętej Mej górze, bo kraj się napełni poznaniem Pana, na kształt wód, które przepełniają morze (Iz 11, 6-9).

\section{2. „Stworzenie z upragnieniem oczekuje objawienia się synów Bożych" $(\operatorname{Rz~8,19)}$}

Starotestamentowa wizja integralności i harmonii stworzenia, promująca przyjazne wobec zwierząt spojrzenie teocentryczne, nie pozostała bez wpływu na zdrowe nurty teologii chrześcijańskiej. Podkreślano, że stworzenia istnieją dla Boga, który miłuje wszystko, co stworzone, ponieważ akt stworzenia jest owocem Jego miłości. Dzięki niemu między Stwórcą a wszystkimi stworzeniami trwają nieprzerwanie subtelne więzi wzajemnych relacji. Święty Jan Chryzostom napisał: „Z pewnością winni jesteśmy zwierzętom życzliwość i łagodność z wielu powodów, a głównie z tego, że ich i nasze pochodzenie jest takie samo"17. Święty Maksym Wyznawca (ok. 580-662) podkreślał: „Bóg, który w swej wszechmocy stworzył wszystkie rzeczy, zawiera je bowiem, łączy i oddziela, a w swej opatrzności łączy istoty rozumne i zmysłowe ze sobą samym i z sobą nawzajem. Wszystkie stworzenia, które ze swej istoty odmienne są od siebie - sprawia On, że łączą się one ze sobą, poprzez tę niepowtarzalną siłę relacji z Nim jako ich źródłem"18. Tak samo, według świadectwa św. Franciszka z Asyżu, widział te więzi i je przeżywał św. Bonawentura: „Gdy rozważał pierwotne źródło wszystkich rzeczy, napełniała go jeszcze większa pobożność, i nazywał nawet najmniejsze stworzenia bratem lub siostrą, wiedział bowiem, że pochodzą z tego samego źródła, co on" ${ }^{19}$. Co więcej, dopatrywano się - i słusznie - również pierwotnego ukierunkowania dzieła stworzenia ku zbawieniu dokonanemu w Jezusie Chrystusie. Święty Atanazy napisał: „Gdy Słowo nawiedziło świętą Marię Dziewicę, Duch przyszedł do niej wraz z nim, a Słowo w Duchu ukształtowało ciało i poddało je sobie, chcąc przez siebie połączyć i oddać całe stworzenie Ojcu, i, zaprowadziwszy pokój, pogodzić w sobie wszystkie rzeczy na niebie i ziemi"20.

Wypowiedź św. Atanazego sugeruje, że szacunek wobec zwierząt i wzgląd na ich dobrostan - motywowane wyłącznie względem na dzieło stworzenia - nie wystarczają. Wiele do myślenia daje też znamienny paradoks: judaistyczna refleksja teologiczna poświęcona zwierzętom (oraz opar-

\footnotetext{
${ }^{17}$ Cyt. za: A. Linzey, dz. cyt., s. 29.

18 Tamże, s. 26.

19 Tamże, s. 29.

20 Tamże, s. 26-27.
} 
te na niej rozporządzenia moralne i prawne) jest znacznie obfitsza aniżeli równoległa refleksja chrześcijańska oraz oparte na niej nauczanie moralne. To, co teologowie chrześcijańscy mają na ten temat do powiedzenia, odwołuje się w zasadzie do Starego Testamentu, często wykorzystując spojrzenie obecne w tradycji żydowskiej. Trzeba zatem z mocą postawić pytanie, czy i w jakim stopniu specyficznie chrześcijańska prawda o wcieleniu Syna Bożego - a także wzgląd na Jego życie i los, których integralnym składnikiem stało się cierpienie i śmierć - stanowiąca sedno orędzia Nowego Testamentu, rzuca światło nie tylko na radykalnie nową kondycję odkupionego człowieka, lecz i na całość stworzenia Bożego, a więc również na teologiczne postrzeganie zwierząt. Dochodzimy do postulatu, który należy sformułować w ten sposób: chrześcijańska teologia zwierząt powinna obficiej aniżeli dotychczas karmić się przemyśleniami z zakresu dobrze rozwijanej i wystarczająco pogłębionej chrystologii, ponieważ bez nich nigdy nie będzie ona prawdziwie chrześcijańska. A zatem: „Bez względu na ostateczne opinie napisał A. Linzey - w sprawie tradycji chrześcijańskiej i jej moralnej spuścizny w dzisiejszym świecie, [...] nastał już najwyższy czas na teologiczną zmianę sposobu myślenia, prowadzącą do zmian w dziedzinie etyki" ${ }^{21}$.

U podstaw refleksji chrystologicznej znajduje się prawda o grzechu prarodziców ludzkości, znanym jako grzech pierworodny, który zasadniczo odmienił kondycję człowieka i świata stworzonego przez Boga. Przed popełnieniem nieposłuszeństwa wobec Boga istniała w świecie harmonia, widoczna w przyjaznej koegzystencji ludzi i zwierząt. Ale grzech ją zepsuł, doprowadzając do antagonizmów, których przejawami stała się wrogość i strach oraz „niewola zepsucia”. Tę myśl zawarł św. Paweł w Liście do Rzymian: „Bo stworzenie z upragnieniem oczekuje objawienia się synów Bożych. Stworzenie bowiem zostało poddane marności - nie z własnej chęci, ale ze względu na Tego, który je poddał - w nadziei, że również i ono zostanie wyzwolone z niewoli zepsucia, by uczestniczyć w wolności i chwale dzieci Bożych. Wiemy przecież, że całe stworzenie aż dotąd jęczy i wzdycha w bólach rodzenia" (Rz 8, 19-22) 22. Zepsucie grzechu, aczkolwiek dopuścił się go człowiek, w tajemniczy sposób objęło wszystkie istoty żywe. „Nasze dziedzictwo - napisał David H. Stern - to również ten ekologicznie zniszczony świat, który pewnego dnia będzie odnowiony (Dz 3, 21; 1 Kor 15,

21 Tamże, s. 9.

22 Zob. L. Mycielski, Przyszłe wyzwolenie stworzenia. Egzegeza teologiczna Rz 8, 19-23, „Analecta Cracoviensia” 1 (1969), s. 120-149; R. Bartnicki, Współczesna a patrystyczna interpretacja Rz 8,19, „Studia Theologica Varsaviensia” 1 (1978), s. 49-65; A. Geniusz, Cierpienia obecnego czasu ,nie stanowia zagrożenia dla [ouk aksia pros] chwaty, która ma się w nas objawić”, „Collectanea Theologica” 2 (1999), s. 27-47. 
23-28; Hbr 2, 8-11; Ap 21, 1)"23. Skoro tak, owoce zbawienia dokonanego przez Jezusa Chrystusa nie mogą się ograniczać jedynie do ludzi, lecz obejmują cały stworzony świat, urzeczywistniając w nim upragnione wyzwolenie. Już w Starym Testamencie pojawiła się bardzo ważna intuicja ${ }^{24}$, że wrogość zwierząt między sobą i ich wzajemne zwalczanie się, a także wrogość i nieufność większości zwierząt wobec człowieka oraz ludzki strach przed nimi, zakończą się wraz z przezwyciężeniem grzechu i nastaniem nowego porządku sprawionego przez Boga ${ }^{25}$.

Prawda o wcieleniu Syna Bożego ${ }^{26}$ oraz wyzwoleniu człowieka i świata $\mathrm{z}$ marności, jaką spowodowały zło i grzech, określa i kształtuje teologiczną refleksję nad zwierzętami na co najmniej cztery zasadnicze sposoby. Po pierwsze, chodzi o chrześcijańskie pogłębienie koncepcji stworzenia, możliwe i niezbędne dzięki należytemu respektowaniu prawdy o wcieleniu. Wnikliwa odpowiedź na kwestię Cur Deus homo? prowadzi do wniosku, że wcielenie stoi na przedłużeniu stworzenia, a więc jest mocnym dowartościowaniem nie tylko ducha, lecz również cielesności ${ }^{27}$. Teolog chrześcijański nie może uniknąć pytania, czy fakt, że Bóg stał się człowiekiem w Jezusie z Nazaretu ma znaczenie wyłącznie dla ludzi, czy też oddziałuje on i skutecznie wpływa na kondycję oraz status całego stworzonego świata. Pojawiają się rozmaite odpowiedzi. Przykładowo, Karl Barth wyprowadzał daleko idące - i w gruncie rzeczy nieprzyjazne zwierzętom - dogmatyczne konkluzje ze stwierdzenia, że „odwieczny Syn Boży, Logos, nie zechciał stać się zwierzęciem czy aniołem, lecz człowiekiem"28. To prawda, ale z drugiej strony, czy byłoby możliwe, by „tak" wobec człowieka, które znalazło wyraz i potwierdzenie we wcieleniu Syna Bożego, miało oznaczać „nie” wobec wszystkich innych stworzeń? Co więcej, skoro człowiek stanowi „koronę stworzenia” i został powołany do podjęcia za nie wielorakiej odpowiedzialności, nie jest i nie może być zatem obojętne, czy i jak wywiązuje się z tej powinności w nowych okolicznościach wejścia Boga w historię. Mentalna przewaga

23 D. H. Stern, Komentarz żydowski do Nowego Testamentu, Prymasowska Seria Biblijna 23, Warszawa 2004, s. 563.

24 Zob. przytoczony wyżej tekst Iz 11, 6-9.

25 Por. hasło Zwierze, w: F. Rienecker, G. Maier, dz. cyt., s. 909; A. P. Kluczyński, Motywy pokoju między zwierzętami w Księdze Izajasza 11, 6-8 i 65, 25, „Roczniki Teologiczne” 1-2 (2008), s. 9-20.

26 Por. zinterpretowany w perspektywie, ,ekologicznej” Prolog Ewangelii według św. Jana:

D. G. Deffenbaugh, D. L. Dungan, dz. cyt., s. 1765-1766.

27 Szerzej W. Chrostowski, Ludzka cielesność jako obraz Boga, „Collectanea Theologica” 4 (2000), s. 5-19.

28 Cyt. za: A. Linzey, dz. cyt., s. 25. 
i wyższość człowieka nad zwierzętami nie oznacza, że jedynym, bądź najważniejszym, sensem istnienia zwierząt jest ich bezwzględne podporządkowanie i oznaczająca wszechstronną eksploatację służba człowiekowi. Stary Testament naucza, że Bóg stworzył zwierzęta i uznał je za „dobre” zanim stworzył człowieka, a więc zostały one stworzone przez Boga i dla Boga. Skoro wszystkie stworzenia istnieją dla Boga, a Bóg nieodwołalnie, bo tego wymaga Jego miłość, związał się z nimi, to człowiek, naśladując Go, nie może zaniedbywać swoich powinności wobec innych stworzeń. Powinien je traktować nie jako istoty bezwarunkowo mu poddane, lecz jako chcianych i danych przez Stwórcę współtowarzyszy swojej egzystencji w Bożym świecie. Nie będzie zatem żadnej przesady w stwierdzeniu, że krzywdzenie zwierząt oznacza w gruncie rzeczy krzywdę wyrządzoną Bogu w tym, co stworzy ${ }^{29}$. Skoro wcielenie Syna Bożego oznacza bezprecedensowe dowartościowanie cielesności, zatem uwzględnianie chrystologii i jej owocne wykorzystywanie stanowi specificum christianorum w refleksji teologicznej wyznawców Chrystusa dotyczącej zwierząt. Trzeba zdecydowanie zaniechać stereotypowego i krzywdzącego przeświadczenia, że „Jezus Chrystus ma olbrzymie znaczenie dla istot ludzkich, lecz jest zupełnie bez znaczenia dla reszty stworzenia" 30 . Dlatego ,panowanie ludzi nad zwierzętami powinno wzorować się na przekazanej nam przez Chrystusa koncepcji panowania widocznego w służeniu" ${ }^{31}$.

Po drugie, sednem chrystologii jest głębsze zrozumienie i naśladowanie Jezusa Chrystusa oraz podjęcie Jego posłannictwa. Nie chodzi wyłącznie o racjonalizację, dzięki której pełniej ogarniamy Chrystusa rozumem, lecz również o przełożenie rozeznania teologicznego na język powinności etycznych i moralnych. Etyka „naśladowania Boga”, właściwa dla Starego Testamentu, zyskuje nowe wymiary i akcenty w etyce „naśladowania Chrystusa” znamionującej Nowy Testament. Im głębsza i bardziej poprawna doktryna chrystologiczna, tym pełniejsze i bardziej skuteczne określenie i realizowanie wynikających z niej imperatywów moralnych. W całym swym życiu i nauczaniu Jezus wyraźnie opowiadał się po stronie ludzi słabszych, biednych i spychanych na margines (Mt 25, 35-37). Jednak tej współczującej i miłosiernej postawy Jezusa oraz wynikających z niej zobowiązań etycznych nie powinno się ograniczać wyłącznie do ludzi, lecz rozciągnąć na wszystko, co słabsze oraz wymagające pomocy i wsparcia. Jest oczywiste, że zwierzęta, nawet największe i najsilniejsze, są słabsze i zazwyczaj bezbronne wobec

29 Tamże, s. 55.

30 E. L. Mascall, The Christian Universe, London 1971, s. 163; cyt. za: A. Linzey, dz. cyt., s. 26 .

31 Tamże, s. 11. 
ludzi, którzy niemal zawsze mają nad nimi przewagę. Zatem, ujmując to konsekwentnie i jasno, ,powinniśmy być dla stworzeń tym, czym Chrystus jest dla nas"32. Ewangelie dostarczają niemało wiedzy o tym, jak Jezus postrzegał $\mathrm{i}$ traktował rozmaite stworzenia ${ }^{33}$. W przypowieściach, nawiązujących do realiów starożytnej Palestyny, nie brakuje szczegółowych nawiązań do potrzeby troski o zwierzęta i sprawowania nad nimi właściwej opieki (Mt 12, 11; Łk 12, 6-7; 13, 15; 14, 5; 15, 4). Tak nasuwa się i zarysowuje postulat służebności ludzi względem innych stworzeń. W perspektywie chrześcijańskiej, upatrującej w człowieku swoistego kapłana stworzenia, nabiera on wyjątkowego znaczenia, co dotyczy zwłaszcza kapłanów jako szczególnej ikony Chrystusa. Nie jest sprawą przypadku, że przy średniowiecznych klasztorach niemal wszędzie istniał tzw. paradisus, czyli „raj”, w którym hodowano zwierzęta i uprawiano rozmaite rośliny, potwierdzając w ten sposób harmonię dzieła stworzenia i niezbywalne powinności człowieka względem innych istot.

Po trzecie, sedno etyki naśladowania Jezusa Chrystusa stanowi wezwanie do podjęcia tego, co w życiu najtrudniejsze i czego symbolem jest krzyż (Mt 10, 38-39 i par.). Chodzi przede wszystkim o obecność i znaczenie cierpienia w życiu i losie Chrystusa, który poświęcił siebie nie tylko za ludzkość, lecz za wszystko, co stworzone. Nowego przemyślenia we współczesnej teologii potrzebuje kosmiczny wymiar krzyża Chrystusa, który nie poprzestaje na podkreślaniu wąsko pojętego antropocentryzmu. Teologia chrześcijańska nie może lekceważyć refleksji nad obecnością różnorodnego cierpienia w całym Bożym świecie. Zbyt często zdarzało się, że w uprawianiu teologii poprzestawano na przesłankach przyrodniczych albo, co najwyżej, psychologicznych, tymczasem decydujące są względy i racje specyficznie teologiczne. Skoro cierpienie Syna Bożego stało się środkiem zbawienia i uświęcenia człowieka i świata, trzeba postawić pytanie o sens wszelkiego otaczającego nas cierpienia, a więc także cierpienia zwierząt. Mimo rozmaitych zapatrywań, punktów widzenia i wrażliwości jest pewne, że zwierzęta, jako istoty żywe i jedyne w swoim rodzaju, nie tylko odczuwają ból i lęk przed cierpieniem, lecz także, w sposób sobie właściwy, przeżywają je. Przytoczywszy wstrząsające opowiadanie autorstwa Helen Waddell, A. Linzey konkluduje: „Jeśli prawdą jest, że Bóg jest Stwórcą i że podtrzymuje cały żyjący świat, to nie do pomyślenia jest, by Bóg nie współuczestniczył w cierpieniu stworzonych istot - również innych niż człowiek" ${ }^{34}$. Ta intuicja znajdowała wyraz

32 Tamże, s. 63.

${ }_{33}$ M. Wolniewicz, Przyroda w nauczaniu Jezusa, „Zeszyty Karmelitańskie” 4 (2002), s. 53-59.

${ }^{34}$ A. Linzey, dz. cyt., s. 91. 
w myśli chrześcijańskiej, przy czym znamienne, że zazwyczaj podejmowali ją i rozwijali nie teologowie, lecz poeci.

Jeżeli teologia rozważa sens cierpienia sprawiedliwych i niewinnych ludzi, co jest jednym z najtrudniejszych problemów teodycei zajmującej się ,usprawiedliwianiem” Boga, nie wolno przeoczyć prawdy, że cierpienia zwierząt, jako istot pozbawionych rozumu i wolnej woli, nie mogą obrażać Boga $^{35}$. A ponieważ zwierzęta doznają najrozmaitszych cierpień, a mając zdolność odczuwania, lękają się i czują zadawany im ból oraz przeczuwają swoją śmierć, zatem należy rozstrzygnąć dylemat, czy to wszystko jest zupełnie bez sensu i jakiegokolwiek znaczenia, czy przeciwnie, ma sens zamierzony i zaakceptowany przez Boga. Chrześcijańska wrażliwość, karmiona orędziem Starego i Nowego Testamentu, podpowiada, że ten ogrom niezasłużonego cierpienia, dotykającego wszystkie stworzenia, nie może być pobawiony nadziei, lecz jest wielkim krzykiem o lepszą przyszłość wszystkiego, co żyje i czuje, a nawet w pewnym sensie taką przyszłość zapowiada i gwarantuje ${ }^{36}$. Wzgląd na cierpienie obecne w świecie, którego cały czas nader boleśnie doświadczają zwierzęta, sprawia, że przyjazne usposobienie wobec nich - jako minimum, a miłość do stworzeń - jako maksimum, powinny się wyrażać nie tylko w przypatrywaniu się cierpiącym istotom, ani nawet w emocjonalnym współodczuwaniu z nimi, lecz w szlachetnej pomocy polegającej na przynoszeniu im ulgi, a także w ponawianiu pytania, czy ów bezmiar cierpienia różnych stworzeń może być w Bożych zamiarach całkowicie bezcelowy i bezowocny. Skoro stale doświadczamy Bożego miłosierdzia i powtarzamy wezwania, by odwzorowywać je względem naszych bliźnich, nie powinno się lekceważyć kwestii, czy ten sam obowiązek miłosierdzia nie powinien być przenoszony i rozszerzony na wszystko, co żyje. Mówiąc inaczej: trzeba bardzo poważnie potraktować pytanie, czy silny i bezkompromisowy antropocentryzm jest w ogóle do pogodzenia z treścią i wymaganiami wiary w Boga jako Stworzyciela i Odkupiciela ludzkości i całego świata. „Budowanie adekwatnej teologii zwierząt - konkluduje A. Linzey - może rozpocząc się tylko wtedy, gdy zdołamy uratować się przed nadmiernym antropocentryzmem. Tylko Bóg - a nie człowiek - jest miarą wszechrzeczy"37. Wniosek brzmi: najważniejszą przesłankę dla przykazania miłości wobec wszystkich stworzeń stanowi wzgląd na to, że Boże „tak” wobec ludzi, urzeczywistnione we wcieleniu Syna Bożego, oznacza zarazem Boże „tak” wobec całości stworzenia. Wielkość i wyjątkowość człowieka polega

${ }^{35}$ W. Chrostowski, Status zwierząt, s. 20-21.

${ }^{36}$ A. Geniusz, Cierpienia, s. 40; oraz: tenże, Nadzieja dla niewinnie cierpiacego stworzenia (Rz 8, 19-22), „Verbum Vitae” 9 (2006), s. 71-104.

${ }^{37}$ A. Linzey, dz. cyt., s. 117. 
na tym, że to rozumie, uznaje, przyjmuje i przekłada na język odpowiednich powinności etycznych.

Po czwarte, teologia chrześcijańska powinna pełniej i szerzej odczytywać i objaśniać przykazanie miłości Boga i bliźniego. Oczywiste, „,bliźnim”, którego miłość została nakazana w Kpł 19, 18, jest nie tylko współwyznawca, lecz - jak uczy Jezus (Łk 10, 30-37) - każdy człowiek. Jednak rosnąca świadomość naszej wielorakiej solidarności z innymi stworzeniami, oparta na przesłankach teologicznych i stale powiększającej się wiedzy przyrodniczej, stawia nas wobec nowego postulatu, nacechowanego znacznie większą wrażliwością, nastawienia wobec tych stworzeń. Dopowiedzenie ,jak siebie samego" wskazuje na nasze pochodzenie i naturę istot stworzonych, co dzielimy również ze zwierzętami ${ }^{38}$, ponieważ wszystko, co istnieje, zostało stworzone przez Boga. Potwierdzenie i rozszerzenie przez Jezusa przykazania miłości bliźniego sprzyja więc temu, by odnieść je również i praktykować wobec naszych ,braci starszych”. Dzięki temu wyczulenie ekologiczne, w naszych czasach większe niż wcześniej, zyskuje kolejną przesłankę, dobrze osadzoną w Ewangelii i pojawiającą się już wcześniej w najlepszych nurtach tradycji chrześcijańskiej.

Istnieje jeszcze jeden aspekt, którego nie powinno się pomijać w rozwijaniu chrześcijańskiej teologii zwierząt. W czasach Starego Testamentu zwierzęta stały się przedmiotem prawodawstwa Mojżeszowego, uczestniczyły na wiele sposobów w losach ludzi, a w świątyni jerozolimskiej przez ponad tysiąc lat składano z nich ofiary. Istniał znamienny paradoks: im więcej ludzie grzeszyli, bądź im częściej zaspokajali swe potrzeby religijne, tym więcej zwierząt przypłacało to życiem. Chociaż ofiary ze zwierząt stanowiły integralną część religii biblijnego Izraela, zachowywano świadomość, że Bóg nie zrzekł się swego prawa własności wobec zwierząt (Ps 50, 10-11). Niemal zawsze silna też była myśl podkreślająca, że ofiary ze zwierząt stanowią znak i zobowiązanie do wewnętrznej przemiany serca i sumienia oraz otwarcia na działanie Boże, które dopiero nadejdzie (Ps 40, 7-8; 51, 18-19). $\mathrm{W}$ tej perspektywie doroczna ofiara składana $\mathrm{z}$ baranka paschalnego, upamiętniająca wybawienie Izraelitów z Egiptu, stanowiła zapowiedź ofiary Nowego Przymierza (Rdz 22, 13; Wj 13, 12-13), natomiast Sługa Pański, którego dramatyczny los zapowiadały cztery pieśni w drugiej części Księgi Izajasza, został porównany do baranka prowadzonego na rzeź (Iz 53, 7).

Wraz z wcieleniem Syna Bożego dokonało się radykalne i trwałe przewartościowanie i przeobrażenie religii biblijnego Izraela. Mimo że w życiu i nauczaniu Jezusa ofiary nie odgrywały widocznej roli, uznawał on ówcze-

38 J. A. Grassi, dz. cyt., s. 378. 
sny system ofiarniczy (Mt 8, 4; Mk 1, 44; Łk 5, 14; 17, 14), lecz wzorem proroków starotestamentowych krytycznie odnosił się do niego (Mt 15, 5; Mk 7, 11) ${ }^{39}$. A jednak kulminację życia Jezusa stanowiła dobrowolna ofiara z życia podjęta za grzechy świata, w której widać wyraźne podobieństwo do składania zwierząt na ofiarę. „Jeden z wymiarów relacji między Jezusem a starotestamentowym systemem ofiarniczym w ujęciu Nowego Testamentu stanowi Jego osobiste utożsamienie się z rozmaitymi aspektami tego systemu" ${ }^{40}$. Jak po kamiennym ołtarzu na dziedzińcu świątyni jerozolimskiej codziennie spływała krew ofiarowanych na nim zwierząt, tak po krzyżu ustawionym na Kalwarii, w bliskim sąsiedztwie świątyni, spłynęła krew Zbawiciela, która uczyniła ofiary Starego Testamentu niepotrzebnymi, dokonała bowiem wiecznego odkupienia ludzkości i świata: „Jeżeli bowiem krew kozłów i cielców oraz popiół z krowy, którymi skrapia się zanieczyszczonych, sprawiają oczyszczenie ciała, to o ileż bardziej krew Chrystusa, który przez Ducha wiecznego złożył Bogu samego siebie jako nieskalaną ofiarę, oczyści wasze sumienia z martwych uczynków, abyście służyć mogli Bogu żywemu" (Hbr 9, 13-14). Starotestamentowa tradycja składania ofiar zyskała zwieńczenie w ofierze Jezusa Chrystusa, która oznacza i sprawia absolutnie nową jakość, polegającą na umożliwieniu pełnej wspólnoty z Bogiem. Jedno z najważniejszych stwierdzeń teologii chrześcijańskiej winno niestrudzenie przypominać i podkreślać, że dzieło zbawienia dokonane przez Chrystusa odmieniło nie tylko grzeszną kondycję człowieka, lecz nadało też zasadniczo nowy kształt pobożności, w której nie trzeba już przelewać krwi zwierząt na ofiary składane Bogu. Ten nowy stan rzeczy stanowi przedsmak pełnej odnowy świata, której z cierpliwą wytrwałością oczekujemy.

\section{Love towards Animals in the Light of the Bible (Summary)}

Rare theological considerations devoted to animals are in a sharp contrast with their place and role in the world and human life. Theologians mostly have stressed their mentioning in biblical accounts of the creation of world (Gen 1-2), as well as have condemned the different forms of bad actions towards them, but there is a lack of specifically Christian considerations based on the God's plan of salvation as realized by Jesus Christ. The author considers four points: 1 . The need for deepening

39 W. Chrostowski, Status zwierząt, s. 21-22.

40 R. E. Averbeck, Offerings and Sacrifices, w: W. A. VanGemeren (red.), Dictionary of Old Testament Theology and Exegesis, t. 4, Paternoster Press 1997, s. 1016. 
of Christian concept of Creation, possible thanks to the respect for the Incarnation; 2. Better understanding and imitation of Jesus Christ, especially as concerns our moral obligations and duties towards animals; 3. Theological reconsideration of the problem of animal's suffering; 4. The ethical and moral reconsideration of the commandment of love. 